\title{
Marine probiotics: increasing coral resistance to bleaching through microbiome manipulation
}

\author{
Phillipe M. Rosado ${ }^{1,2} \cdot$ Deborah C. A. Leite ${ }^{1}$ - Gustavo A. S. Duarte $\mathbb{1}^{1,2} \cdot$ Ricardo M. Chaloub $^{3} \cdot$ Guillaume Jospin $^{4}$. \\ Ulisses Nunes da Rocha ${ }^{5}$. João P. Saraiva ${ }^{5}$. Francisco Dini-Andreote ${ }^{6} \cdot$ Jonathan A. Eisen $^{4,7,8}$ • David G. Bourne ${ }^{9,10}$. \\ Raquel S. Peixoto ${ }^{1,2,4}$
}

Received: 18 April 2018 / Revised: 3 November 2018 / Accepted: 17 November 2018 / Published online: 5 December 2018

(c) The Author(s) 2018. This article is published with open access

\begin{abstract}
Although the early coral reef-bleaching warning system (NOAA/USA) is established, there is no feasible treatment that can minimize temperature bleaching and/or disease impacts on corals in the field. Here, we present the first attempts to extrapolate the widespread and well-established use of bacterial consortia to protect or improve health in other organisms (e.g., humans and plants) to corals. Manipulation of the coral-associated microbiome was facilitated through addition of a consortium of native (isolated from Pocillopora damicornis and surrounding seawater) putatively beneficial microorganisms for corals (pBMCs), including five Pseudoalteromonas sp., a Halomonas taeanensis and a Cobetia marina-related species strains. The results from a controlled aquarium experiment in two temperature regimes $\left(26^{\circ} \mathrm{C}\right.$ and $\left.30^{\circ} \mathrm{C}\right)$ and four treatments (pBMC; pBMC with pathogen challenge - Vibrio coralliilyticus, VC; pathogen challenge, VC; and control) revealed the ability of the pBMC consortium to partially mitigate coral bleaching. Significantly reduced coral-bleaching metrics were observed in pBMC-inoculated corals, in contrast to controls without pBMC addition, especially challenged corals, which displayed strong bleaching signs as indicated by significantly lower photopigment contents and $F_{v} / F_{m}$ ratios. The structure of the coral microbiome community also differed between treatments and specific bioindicators were correlated with corals inoculated with pBMC (e.g., Cobetia sp.) or VC (e.g., Ruegeria sp.). Our results indicate that the microbiome in corals can be manipulated to lessen the effect of bleaching, thus helping to alleviate pathogen and temperature stresses, with the addition of BMCs representing a promising novel approach for minimizing coral mortality in the face of increasing environmental impacts.
\end{abstract}

Electronic supplementary material The online version of this article (https://doi.org/10.1038/s41396-018-0323-6) contains supplementary material, which is available to authorized users.

Raquel S. Peixoto

raquelpeixoto@micro.ufrj.br

rspeixoto@ucdavis.edu

1 Institute of Microbiology, Federal University of Rio de Janeiro (UFRJ), Rio de Janeiro, Brazil

2 IMAM-AquaRio - Rio de Janeiro Aquarium Research Center, Rio de Janeiro, Brazil

3 Instituto de Química, Universidade Federal do Rio de Janeiro (UFRJ), Rio de Janeiro, Brazil

4 Genome Center, University of California, Davis, CA, USA

\section{Introduction}

Shallow-water tropical corals build the structural framework that supports the enormous macro- and microbial biological diversity found in reef ecosystems $[1,5]$. Despite their key ecological role, coral reefs are threatened by many global

5 Department of Environmental Microbiology, Helmholtz Centre for Environmental Research - UFZ, Leipzig, Germany

6 Department of Microbial Ecology, The Netherlands Institute of Ecology (NIOO-KNAW), Wageningen, The Netherlands

7 Evolution and Ecology, University of California, Davis, CA, USA

8 Medical Microbiology and Immunology, University of California, Davis, CA, USA

9 College of Science and Engineering, James Cook University, Townsville, Australia

10 Australian Institute of Marine Science, Townsville, Australia 
impacts, including increasing seawater temperatures that push corals beyond their thermal thresholds, resulting in the breakdown of the close symbiotic interaction between the hosts and their photosynthetic dinoflagellate partners (Symbiodium). The ecological disruption of this symbiotic partnership manifests as bleaching, and recent global bleaching events have resulted in extensive loss of reef habitat [3, 6-8]. The Intergovernmental Panel on Climate Change (IPCC) predicts rising global temperatures between $0.4{ }^{\circ} \mathrm{C}$ and $1.1^{\circ} \mathrm{C}$ by 2025 , and, in the most pessimistic scenario, up to $5.8^{\circ} \mathrm{C}$ by 2100 (IPCC, 2013), potentially resulting in a catastrophic impact on reef ecosystems [9].

Management priorities for coral reefs have moved beyond documenting their declines, toward investigating potential approaches for mitigating climate impacts, for instance by enhancing coral resistance and resilience using approaches such as assisted recovery and restoration [1013]. While global action on climate combined with local efforts to actively protect corals from impacts remains a priority, the dire outlook for coral reefs over the coming century has necessitated investigation of other approaches to build resistance and/or resilience into coral populations. Introduction of selectively bred resistant corals has been proposed as a novel approach; however, the native corals' ability to cope with predicted warming and other environmental stresses (e.g., pathogens) also needs investigation [13].

Microorganisms are key players supporting the functioning and health of multi-cellular life and the ecosystems in which they thrive. Microbiome engineering, i.e., microbial composition and/or function changes, can be achieved through different approaches with these strategies reviewed elsewhere [14]. Manipulation of microbiome communities has been postulated as a key strategy to 'engineer' and manipulate host phenotypes and ecosystem functioning [14]. Microbiome engineering has also been indicated as an important strategy for the "smart farming" concept [15], which applies technology to improve agricultural quality, quantity, and sustainability [16]. Such a strategy has been used to improve sustainable agricultural practices [17-19], including the use of biological control of agricultural pests, i.e., the application or manipulation of living biological agents to control plant pathogens and/or insects [20], and the use of Plant Growth-Promoting Rhizobacteria (PGPRs) [21] to improve plant development [22-24]. These are key approaches supporting agricultural activities globally [25], as well as the use of specific probiotics for humans [26]. Bioaugmentation, which consists of increasing the numbers of native bacteria to perform bioremediation of pollutants [27], has been successfully applied to protect corals against oil spills [28]. Although manipulation of microbiomes has been widely (and successfully) used for terrestrial ecosystems (including probiotics for humans [26], agriculture [21-25], and bioremediation [27]), microbiomes are largely underexploited in marine ecosystems.

The manipulation of microbiomes associated with corals (Beneficial Microorganisms for Corals, BMC) [29] was recently proposed as a promising (albeit yet-to-be-explored) tool to improve coral health, potentially promoting resistance and resilience in coral populations and ultimately aiding recovery of impacted reefs [29-32]. BMCs can enhance coral fitness through their symbiotic relationships with the host, including the cycling of nutrients within the holobiont [33-35] or antagonism/exclusion of potential pathogens (biological control) [36-38]. Here, we refer to these organisms as BMCs when their beneficial effects are known. When the effects on coral are simply hypothesized but not yet established, we refer to these organisms as "putative beneficial microorganisms for coral" (pBMCs). BMCs can both form a consistent part of the native coral microbiome and/or be acquired from the surrounding water during adverse environmental conditions [29]. Environmental conditions can shift the coral microbiome by shuffling the relative abundance of existing microbial community members or switching where the microbial communities are exchanged. These changes in microbiome assemblages may also be passed on faithfully through generations to increase host fitness a process termed microbiome-mediated transgenerational acclimatization (MMTA) [39]. The ability to manipulate the coral microbiome through the addition of BMCs, aiming to improve coral resistance to environmental stresses, needs a detailed investigation to establish the effectiveness of this approach, the potential costs, and the exact mechanisms of interaction between the BMCs and the coral host. Here, we describe a successful manipulation of the coral microbiome through the addition of pBMCs that significantly improved coral resistance when exposed to increased seawater temperature, and mitigated the physiological impact on corals challenged with the temperature-dependent pathogen Vibrio coralliilyticus (VC).

\section{Materials and methods}

\section{Ethics approval and consent to participate}

The microbial survey permit was obtained from $\mathrm{CNPq}$ (Brazilian National Council for Scientific and Technological Development).

\section{Isolation of BMCs}

Three colonies of Pocillopora damicornis were used as the source material for isolation of pBMCs. Corals colonies were originally from the Indo-Pacific Ocean. After 
collection, they were cultured in aquariums from the Coral Vício Company (Peruíbe, Brazil), Robson Aragão Aquariums Nova Friburgo (Rio de Janeiro, Brazil) Leonardo Carvalho, Igor Albergaria, and Marcelo Cunha Aquariums (Rio de Janeiro). We do not have information about the exact geographic location from where these colonies were taken. Samples from all these sources were used for the isolation of $\mathrm{pBMC}$ and the experimental set-up. Corals were kept for 60 days in a $390 \mathrm{~L}$ aquarium with artificial seawater (Red Sea Salt, Red Sea, USA), and a water flow rate of $10,000 \mathrm{~L}$ per hour at the temperature of $26^{\circ} \mathrm{C}$ and $\mathrm{pH}$ of 8.1. Triplicate macerates obtained from each coral colony (ca. $1 \mathrm{~g}$ ) and triplicate $100 \mu \mathrm{L}$ samples of the surrounding water were suspended in $0.85 \%$ sterile saline solution (9 $\mathrm{mL}$ ) and then shaken with glass beads for $16 \mathrm{~h}$. Subsamples $(100 \mu \mathrm{L})$ of $10^{-3}, 10^{-4}$, and $10^{-5}$ dilutions were inoculated into Petri dishes containing $20 \mathrm{~mL}$ of marine agar (MA) medium (Marine Agar Zobell 2216, Himedia Laboratories, Mumbai, India). A total of 53 bacterial colonies were isolated based on colony morphology, with 30 isolates derived from macerated slurries of $P$. damicornis and 23 isolates from the surrounding water. The collection of isolates was screened for selected pBMC functional attributes [29].

The Vibrio coralliilyticus (VC) YB strain (DSM19607), a temperature-dependent pathogen of the coral P. damicornis [40, 41], was purchased from DMSZ (Deutsche Sammlung von Mikroorganismen und Zellkulturen $\mathrm{GmbH}$, Germany), and used in subsequent aquarium experiments. This pathogen was also used in antagonistic assays with selected bacterial strains. The strain was stored in $80 \%$ glycerol at $-80{ }^{\circ} \mathrm{C}$ and subsequently recovered and grown on MA medium at $28{ }^{\circ} \mathrm{C}$ for $16 \mathrm{~h}$ for experimental trials.

\section{Screening for pBMC traits}

The screening for $\mathrm{pBMCs}$ was performed based on previously established protocols [29] with selected pBMC traits consistent with the focus of the experiment, i.e., protection against thermal and disease stresses. This included catalase producers to reduce the concentration of reactive oxygen species (ROS), nitrogen cycling, dimethylsulfoniopropionate (DMSP) degradation, and antagonistic bacteria to promote the biological control of pathogens.

Coral-derived bacterial isolates with antagonistic activity against $V$. coralliilyticus were identified through the agardiffusion method described by Giambiagi-de Marval and colleagues (1990) [42]. Briefly, $20 \mu \mathrm{L}$ of each bacterial strain was spot-inoculated in a Petri dish containing 3\% MA medium. Six 'spots' were placed in each Petri dish, each spot representing a different isolate. Plates were incubated at $28^{\circ} \mathrm{C}$ for $16 \mathrm{~h}$, after which the plates were inverted on sterile aluminum foil and $1 \mathrm{~mL}$ of chloroform-soaked cotton was placed on the inner surface of each dish for $30 \mathrm{~min}$. The antagonistic activity was determined using VC YB as an indicator strain, previously cultured in 3\% $\mathrm{MB}$ medium (Marine Broth 2216, Himedia Laboratories) and inoculated $\left(1 \mu \mathrm{L} \mathrm{mL}^{-1}\right)$ in $3 \% \mathrm{MA}$ semi-solid medium, to be poured on the surface of the plates containing the colonies previously inactivated with chloroform. These plates were incubated at $28^{\circ} \mathrm{C}$ for $16 \mathrm{~h}$, and the production of antimicrobials was indicated by inhibition halos around the colony spots. Inhibition halos $\geq 5 \mathrm{~mm}$ were considered indicative of inhibitory activity.

All strains were tested for the production of catalase [43]. Briefly, $50 \mu \mathrm{L}$ of $3 \%(\mathrm{v} / \mathrm{v})$ hydrogen peroxide was deposited on a microscope slide and mixed with $0.5 \mathrm{~mL}$ of the liquid culture of the test microorganism, previously grown at $28^{\circ} \mathrm{C}$ for $16 \mathrm{~h}$. If bubbles appeared, the organism was considered catalase-positive, and classified as + (ca. $25 \%$ of the surface covered with bubbles) ++ (ca. $50 \%$ of the surface covered with bubbles),++ (ca. $75 \%$ of the surface covered with bubbles), or ++++ (ca. $100 \%$ of the surface covered with bubbles).

\section{BMC-PCR screening and bacterial $16 \mathrm{~S}$ rRNA gene sequencing}

Bacteria involved in nutrient cycling, which may improve coral fitness through nitrogen fixation or sulfur cycling (e.g., DMSP degradation), were also selected based on the gene repertoire. Total genomic DNA was isolated from each coral-derived bacterial isolate, using the Wizard Genomic DNA Purification kit (Promega, Madison, WI, USA). Subunits of the nitrogenase (nifH), nitrification (nirK) and DMSP degradation ( $d m d A$ ) gene complexes were PCRamplified from the genomic DNA samples using PCR. For the nifH gene, we used the primer set PolF (5'-TGC GAT CCG AAA GCC GAC TC-3') and PolR (5'-ATG GCC ATC ATT TCA CCG GA-3') [44]. For the nirK gene, we used the primer set $\mathrm{F} 1 \mathrm{aCu}\left(5^{\prime}\right.$-ATC ATG GTC CTG CCG CG-3') and R3Cu (5'-TTG GTG TTA GAC TAG CTC CG$3^{\prime}$ ) [45]. For the $d m d A$ gene, we used the primer set $\mathrm{D} /$ allspFP (5'-TAT TGG TAT AGC TAT-3') and D/all-spRP (5'-TAA ATA AAA GGT AAA TCG C-3') [46]. The PCR was performed using $5 \mu \mathrm{L}$ of $10 \mathrm{X}$ buffer, $2.0 \mathrm{mM} \mathrm{MgCl} \mathrm{Mg}_{2}$, $0.2 \mathrm{mM}$ dNTPs, $5 \mathrm{mM}$ of each primer, ca. 2-4 $\mathrm{ng}$ of genomic DNA, and 2.5 U Taq DNA polymerase (Promega), in a final volume of $50 \mu \mathrm{L}$. The thermal-cycling protocols were as follows: nifH, $94{ }^{\circ} \mathrm{C}$ for $3 \mathrm{~min} ; 30$ cycles of $94{ }^{\circ} \mathrm{C}$ for $1 \mathrm{~min}, 55^{\circ} \mathrm{C}$ for $1 \mathrm{~min}$, and $72{ }^{\circ} \mathrm{C}$ for $2 \mathrm{~min}$; and a final extension cycle of $10 \mathrm{~min}$ at $72^{\circ} \mathrm{C}$; nirK, $94{ }^{\circ} \mathrm{C}$ for $2 \mathrm{~min}$; 28 cycles of $94{ }^{\circ} \mathrm{C}$ for $30 \mathrm{~s}, 57^{\circ} \mathrm{C}$ for $1 \mathrm{~min}$, and $72^{\circ} \mathrm{C}$ for 1 min; and a final extension cycle of $10 \mathrm{~min}$ at $72^{\circ} \mathrm{C}$; and dmdA, $94^{\circ} \mathrm{C}$ for $2 \mathrm{~min} ; 35$ cycles of $94{ }^{\circ} \mathrm{C}$ for $20 \mathrm{~s}, 42^{\circ} \mathrm{C}$ for $30 \mathrm{~s}$, and $68^{\circ} \mathrm{C}$ for $30 \mathrm{~s}$; and a final extension cycle of 5 
min at $68^{\circ} \mathrm{C}$. Though we successfully detected the presence of these amplicon products, the amplicons were not sequenced and validated through cloning and sequencing. As such, this approach was used as a proxy for selection of pBMCs. A total of 19 bacterial isolates were selected based on positive amplification signals for one of the three functional genes, and the nearly full-length $16 \mathrm{~S}$ rRNA gene was PCR-amplified from the genomic DNA samples, using the primer set $27 \mathrm{f}\left(5^{\prime}\right.$-AGA GTT TGA TCA TGG CTC AG-3') and $1492 \mathrm{r}\left(5^{\prime}\right.$-GTT TAC CTT GTT ACG ACT T-3') [47]. The PCR was performed using $5 \mu \mathrm{L}$ of $10 \mathrm{X}$ buffer, $2.0 \mathrm{mM}$ $\mathrm{MgCl}_{2}, 0.2 \mathrm{mM}$ dNTPs, $5 \mathrm{mM}$ of each primer, ca. 2-4 ng of genomic DNA, and 2.5 U Taq DNA polymerase (Promega), in a final volume of $50 \mu \mathrm{L}$. The thermal-cycling protocol was as follows: $94^{\circ} \mathrm{C}$ for $3 \mathrm{~min} ; 35$ cycles of $94^{\circ} \mathrm{C}$ for $40 \mathrm{~s}$, $55^{\circ} \mathrm{C}$ for $1 \mathrm{~min}$, and $72^{\circ} \mathrm{C}$ for $2 \mathrm{~min}$; and a final extension cycle of $10 \mathrm{~min}$ at $72{ }^{\circ} \mathrm{C}$. The PCR products were purified using the GFX PCR DNA and Gel Band Purification kit (GE Healthcare, Little Chalfont, UK) and then sequenced (Macrogen Inc., Seoul, South Korea) using the primers $27 \mathrm{f}$, 1492r, 532 (5'-CGT GCC AGC AGC CGC GGT AA-3') and 907 (5'-CCG TCA ATT CMT TTG AGT TT-3') to provide the nearly full-length $16 \mathrm{~S}$ rRNA gene sequence of each isolate [47]. The sequencing electropherograms were processed using The Ribosomal Database Project II (RDP) [48] to remove low-quality bases. Sequences of each isolate were assembled into contigs using Bioedit 7.0.5.3 [49]. The bacterial $16 \mathrm{~S}$ rRNA gene sequences were analyzed using BLASTn [50]. All sequences were deposited in the NCBI database under accession number SUB3733320.

\section{Preparation of the BMC consortium}

Five bacterial strains isolated from coral tissue and two from the surrounding water were chosen to compose the pBMC consortium. The selection was based on the presence of pre-defined genetic and/or phenotypic characteristics (Supplementary Table S1). The cell number of each individual pBMC grown was estimated using optical-density spectrophotometer $\left(\mathrm{OD}_{600}\right)$ (UV-1800 Spectrophotometer, Shimadzu, Kyoto, Japan) measurements for cultures grown at $26^{\circ} \mathrm{C}$ in $100 \mathrm{~mL}$ of $\mathrm{MB}$ medium for $6,12,20,28,38$, and $48 \mathrm{~h}$, and correlated directly with the number of colonyforming units (CFUs) of each strain at each time point. The CFU numbers were assessed using serial dilutions $\left(10^{-4}\right.$, $10^{-5}$, and $\left.10^{-6}\right)$ of replicates $(n=3)$ of each strain, which were plated in triplicate on MA. A volume of $10 \mu \mathrm{L}$ of each dilution was applied to MA plates, and colonies were counted with the aid of a colony counter [51], at each collection time point (i.e., 6, 12, 20, 28, 38, and $48 \mathrm{~h}$ ). Results were normalized to the volume of $1 \mathrm{~mL}$ of medium to estimate the cell number at each sampling time. $28 \mathrm{~h}$ after inoculation in $100 \mathrm{~mL}$ of $\mathrm{MB}$ medium, all strains had reached $3.5 \times 10^{6}$ viable cells $\mathrm{mL}^{-1}$. Cultures were centrifuged at $5000 \mathrm{~g}$ for $2 \mathrm{~min}$ and cell pellets were washed 3 times in $\mathrm{NaCl}(0.85 \%)$, followed by centrifugation at $5000 \mathrm{~g}$ for $2 \mathrm{~min}$, and re-suspended in $30 \mathrm{~mL}$ of $\mathrm{NaCl}(0.85 \%)$, to reach the concentration of $10^{7}$ viable cells $\mathrm{mL}^{-1}$. At this stage, CFU counts were performed (as previously described), to confirm that all strains were at $10^{7}$ viable cells $\mathrm{mL}^{-1}$. Also, an antagonism test (as previously described) was performed for all strains, to exclude isolates that showed antagonistic activity against each other within the selected pBMC strains. Equal volumes of $30 \mathrm{~mL}$ of pBMC$\mathrm{NaCl}(0.85 \%)$ solution of each isolate were mixed, resulting in a total volume of $210 \mathrm{~mL}$ pBMC- $\mathrm{NaCl}(0.85 \%)$ solution containing $10^{7}$ cells $\mathrm{mL}^{-1}$ of each isolate.

\section{Mesocosm experimental design}

The experimental set-up encompassed 24 individual 1.3-L aquariums, placed in water baths to maintain temperature. Three $P$. damicornis colonies that had been maintained in the original aquaria for $\sim 8$ months and for 60 days in the experimental tanks were fragmented into smaller coral nubbins $($ ca. $5 \mathrm{~cm}$ ) representing sampling units, i.e., single fragments for each treatment and sampling time. Each treatment was represented by 3 individual aquariums and each aquarium contained 3 coral nubbins (one for each sampling time), and treatments were randomly distributed among water baths (Fig. 1). Each aquarium had individual $26 \mathrm{~L}$ circulation sumps to form a circulating loop (Supplementary Fig. S1). The water circulation between aquarium/ sump was performed by a water pump (Mini A, Sarlo Better, São Caetano do Sul, Brazil). Importantly, there was no water exchange between/among aquariums and water baths. The aquariums were supplied with artificial seawater (OceanTech, Porto Alegre, Brazil). The seawater flow rate between the aquarium and each individual 26-L sump was $250 \mathrm{~mL} \mathrm{~min}^{-1}$ for each aquarium, providing a tenfold replacement of the volume every hour. In addition, partial exchanges of $20 \%$ of the sumps were made every 3 days. The aquariums received only natural sunlight and therefore followed the natural day/night cycles; the experiment was conducted during the austral spring, with sunrise at ca. 06:00 and sunset at ca. 19:00 h. The experiment was covered with a $70 \%$ shade screen, resulting in $250 \mu \mathrm{mol}$ photons $\mathrm{m}^{-2} \mathrm{~s}^{-1}$ at noon, which is consistent with the average parameters measured in the coral donor aquariums. One $1,000 \mathrm{~L}$ water tank (master tank), which was kept at $18^{\circ} \mathrm{C}$ and interconnected with all four water baths, was used for cooling when necessary. Water pumps (Better 2000, Sarlo Better) in the master tank fed the cold water to the water baths, and the water was returned through two holes in the side of each water bath (Supplementary Fig. S1). Heating (when necessary) was achieved by using six $100 \mathrm{~W}$ heaters 


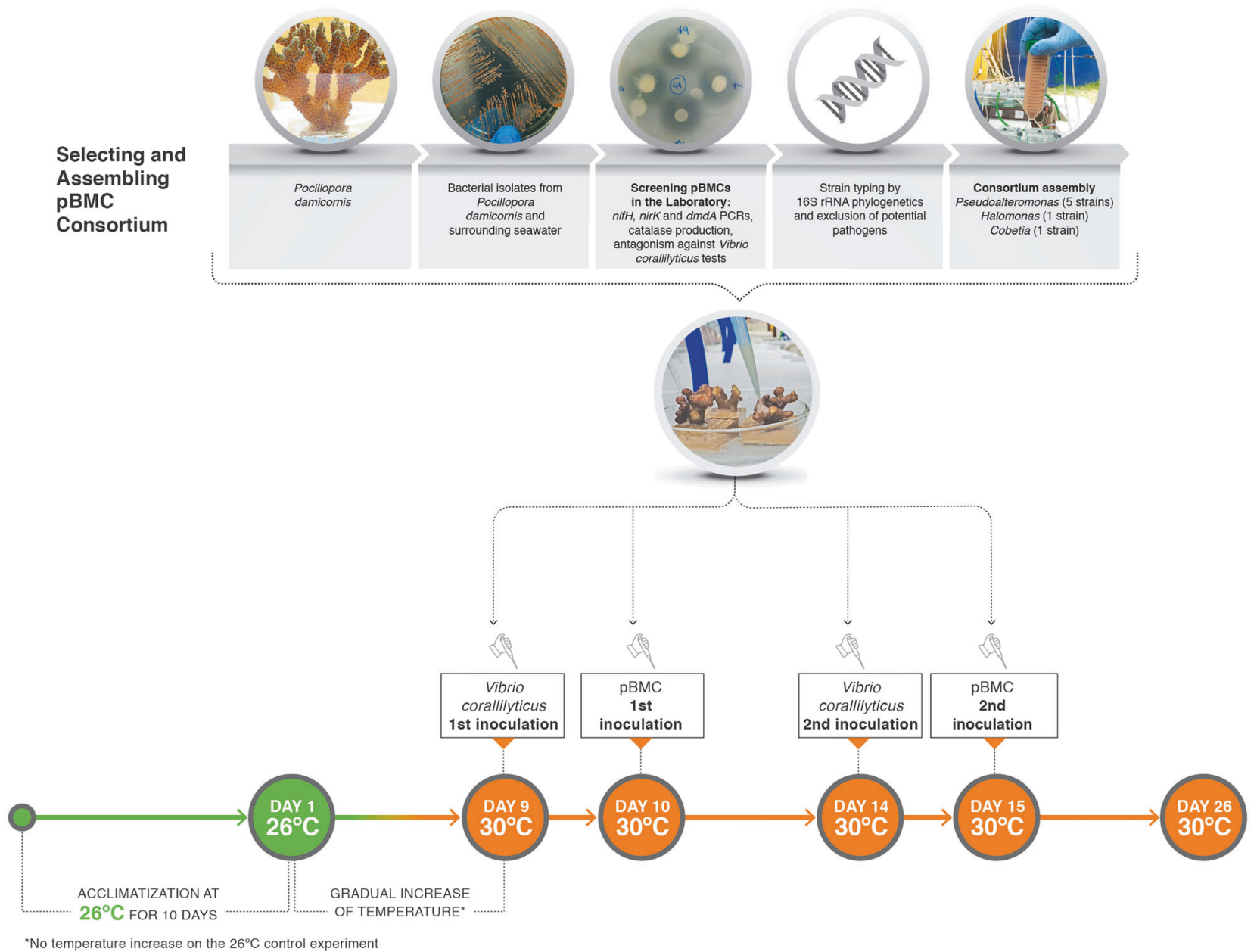

Fig. 1 Flowchart showing the experiment overview. The bacterial isolates screened for BMC features were obtained from Pocillopora damicronis nubbins and surrounding water, then selected and assembled as a consortium. The following treatments were tested: Vibrio ( $n$ $=3), \mathrm{pBMC}+\mathrm{VC}(n=3)$, control (no pBMC or Vibrio corallilyticus

(Atman, China) in each water bath. The water in each water bath was circulated and mixed by two aquarium pumps (SB 1000 A, Sarlo Better) to maintain homogeneous temperatures. The temperature of the water baths was controlled with Full Gauge controls MT-518ri (Canoas, Brazil) connected to heaters and pumps that fed the cooled water from the master tank to the water baths. The temperature of each aquarium was also measured twice daily. Physical and chemical parameters of the water, including $\mathrm{pH}$, salinity, and dissolved oxygen (DO) were measured every 2 days (Supplementary Table S2).

\section{BMC mesocosm experiment}

Two temperature regimes $\left(26^{\circ} \mathrm{C}\right.$ and $\left.30^{\circ} \mathrm{C}\right)$ and 4 treatments were compared in the mesocosm experiment: (i) control samples (CTR) without inoculation of pBMC or inoculation) $(n=3)$ and $\mathrm{pBMC}(n=3)$, at $30^{\circ} \mathrm{C}$. The aquariums with different treatments were randomly distributed. A parallel set of the same experiment was performed at $26^{\circ} \mathrm{C}$, as a control, where the temperature was not raised at any time

VC; (ii) VC, pathogen inoculation $\left(10^{5}\right.$ cells of Vibrio coralliilyticus, at days 9 and 14); (iii) pBMC, consortium inoculation $\left(10^{7}\right.$ cells of the pBMC consortium, at days 10 and 15); and (iv) $\mathrm{pBMC}+\mathrm{VC}$, pathogen $\left(10^{5}\right.$ cells of Vibrio coralliilyticus inoculated at days 9 and 14) and consortium ( $10^{7}$ cells of the pBMC consortium inoculated at days 10 and 15).

Following the initial 10-day coral acclimation period at $26^{\circ} \mathrm{C}$, in four of the treatments, the temperature was gradually increased from day $1(22 / 10 / 2016)$ to day $9(30 / 10 /$ 2016) until it reached $30^{\circ} \mathrm{C}$. As the peak temperature was reached on day 9 , this day was used as the starting point for the manipulation experiment (Fig. 1). The experiment was carried out for a total of 26 days. In a parallel experiment, the same treatments were maintained at $26^{\circ} \mathrm{C}$ until day 26 . Samples were taken from control aquariums at days 1 and 9 (at this time-point all aquariums were controls, i.e. before 
$\mathrm{VC}$ or pBMC inoculation), and from all treatments on day 26. The protocol used for the inoculation of the pBMC consortium consisted of removing the coral fragments from the aquarium, placing them in a sterile Petri dish, and immediately inoculating $1 \mathrm{~mL}$ of the pBMC-NaCl $(0.85 \%)$ solution, consisting of $1 \times 10^{7}$ cells of the pBMC consortium, or $1 \times 10^{5}$ cells of the VC YB-NaCl $(0.85 \%)$ solution directly onto the coral fragments. After inoculation, the fragments were carefully returned to the aquariums and the individual Petri dishes were rinsed into the aquarium water. The control fragments were treated in a similar manner, using a sterile saline solution. VC YB was inoculated at days 9 and 14, and the pBMC consortium was inoculated at days 10 and 15 (Fig. 1). The pBMC consortium was inoculated a day after $\mathrm{VC}$ to provide an 'advantage' to the pathogen in the system. In doing so, assess if the pBMC treatment is effective, even when the pathogen is present at high abundance.

\section{Quantification of parameters associated with coral health}

The color of the coral tissues was analyzed using standard photographs taken on days 1,9 , and 26 of the experiment. Photographs were analyzed in comparison to the Coral Color Reference Chart $[52,53]$. For each photograph, the mean gray value of the chart squares was measured (in triplicate) using Photoshop CC 2015, and a standard color curve was created. The mean gray value was calculated for each coral fragment per time point, and the standard curve was used to relate the gray value to a color score. Changes in color per time point were calculated as the final color value minus the initial value. Statistical differences of changes in color analyses were determined using Student's $t$-test.

The photosynthetic efficiency of Symbiodinium was assessed using pulse-amplitude-modulated (PAM) fluorometry as a proxy for coral holobiont health [54]. We used a submersible diving-PAM system (Walz $\mathrm{GmbH}$, Effeltrich, Germany) fitted with a red-emitting diode (LED, peak at $650 \mathrm{~nm}$ ) and an 8-mm standard glass fiber-optic probe, which was positioned above the oral disk of the polyps. To avoid interference from diurnal photo-inhibition artefacts, measurements were taken after sunset to ensure full recovery of the reaction centers. The maximum quantum yield of PSII photochemistry was determined as $F_{v} / F_{m}$, where $F v$ was obtained as $F m-F o$. Fo is the initial fluorescence signal detected under the modulated measuring light of the PAM (weak pulsed light $<1 \mu \mathrm{mol}$ photons $\mathrm{m}^{-2} \mathrm{~s}^{-1}$ ) and $F m$ is the maximum fluorescence level detected using a short saturating pulse of actinic light. The diving-PAM was configured as follows: Measuring Light Intensity $(\mathrm{MI})=5$, Saturation Pulse Intensity $(\mathrm{SI})=8$, Saturation Pulse Width $(\mathrm{SW})=$
0.8 , Gain $(\mathrm{G})=3$, and Damping $(\mathrm{D})=2$. Throughout the experiment, the same coral nubbin from each replicate $(n=$ 3 nubbins) was used to measure chlorophyll fluorescence at different sampling times. Statistical differences of $F_{v} / F_{m}$ analyses were determined using analysis of variance (ANOVA) with STATISTICA 10 software (StatSoft, Tulsa, OK, USA) followed by a Tukey post-hoc test.

\section{Coral microbiome data analyses}

One entire $P$. damicornis coral nubbin was removed from each aquarium ( 3 aquariums per treatment) at each sampling time, and macerated in a mortar under dry conditions, using a pestle. Total DNA was extracted from $0.5 \mathrm{~g}$ of the macerated tissue, using the Qiagen DNAeasy Power Soil kit (Qiagen, Hilden, Germany). The DNA concentration was determined using a Qubit fluorometer (Invitrogen) and subsequently stored at $-80{ }^{\circ} \mathrm{C}$.

Quantifications of the bacterial 16 S rRNA genes (for total bacteria) and dnaJ genes (used as a proxy for the abundance of VC) [55] were obtained using quantitative PCR (qPCR). The bacterial $16 \mathrm{~S}$ rRNA gene assay was based on the SYBR-green chemistry, with reactions performed in an ABI Prism 7300 Cycler (Applied Biosystems, Darmstadt, Germany) in $20 \mu \mathrm{L}$ reactions containing $10 \mu \mathrm{L}$ GoTaq qPCR Master Mix $2 \times$ (Promega), $2 \mu \mathrm{L}$ of DNA template (standardized to $20 \mathrm{ng}$ ) and $0.25 \mathrm{mM}$ each of primers $357 \mathrm{f}$ and 529r [56], supplemented with $0.5 \mu \mathrm{L}$ of 20 $\mathrm{mg} \mathrm{mL}^{-1}$ of BSA. PCR conditions consisted of an initial denaturation step of $95^{\circ} \mathrm{C}$ for $5 \mathrm{~min}, 35$ cycles of $95^{\circ} \mathrm{C}$ for $1 \mathrm{~min}, 57^{\circ} \mathrm{C}$ for $1 \mathrm{~min}$, and $72{ }^{\circ} \mathrm{C}$ for $45 \mathrm{~s}$ [57]. For estimated dnaJ gene abundances, the assay consisted of $10 \mu \mathrm{L}$ GoTaq qPCR Master Mix $2 \times$ (Promega), and $0.25 \mathrm{mM}$ each of primers Vc_dnaJ_F1 and Vc_dnaJ_R1 [55]. The amplification reactions were performed with an initial denaturation step at $94{ }^{\circ} \mathrm{C}$ for $3 \mathrm{~min}$, followed by 40 cycles of $95^{\circ} \mathrm{C}$ for $15 \mathrm{~s}$ (denaturation) and $60{ }^{\circ} \mathrm{C}$ for $60 \mathrm{~s}$ (annealing/extension). All samples were quantified in triplicate reactions, and sterile $\mathrm{H}_{2} \mathrm{O}$ was used as negative controls. Gene abundances were inferred for each sample, based on standard curves constructed using known concentrations of plasmid DNA extracted from a small fragment of Escherichia coli 16 S rRNA gene (357-529 bp) inserted into a pGEM ${ }^{\circledR}-\mathrm{T}$ Easy Vector System (Promega), and grown in E. coli JM109 strain. The specificity of the amplification was confirmed by melting-curve analysis. Statistical differences of qPCR analyses were determined using analysis of variance (ANOVA) followed by a Tukey post-hoc test.

The V4 variable region of the bacterial $16 \mathrm{~S}$ rRNA gene was amplified using the primer set 515 F/806 R. Paired-end $(2 \times 250 \mathrm{bp})$ sequencing was carried out at the Argonne National Laboratory (Lemont, IL, USA) in the Next 
Generation Sequencing Core on an Illumina Miseq. A total of 3,134,212 sequences ranging from 27,632 to 173,206 pairs of reads per sample (average of 76,444 pairs of reads per sample) were obtained from two sequencing runs. Raw reads were trimmed to 240 base pairs for the forward reads and 160 for the reverse reads, allowing for a maximum of 2 errors per mate, no ambiguous bases, and a Qscore $\geq 20$. A total of 2,022,620 reads passed quality control, with an average of 49,332 reads per sample. By using the DADA2 tutorial, after error learning, dereplication, read merging and chimera removal, we obtained a total of 3214 unique features that were subsequently filtered for Bacterial taxa and against Mitochondria and Chloroplast (Phyloseq 1.22.3). The taxonomy was assigned using DADA2 and the SILVA v128 dataset. Additional taxonomy matching was required to filter out features mapping to the host coral mitochondria. Blastn (version 2.6.0 + ) was used to match the features to the reference sequences (EF526303.1 and EU400214.1) using default values. The features discarded had a $97.9 \%$ match or better. Prior to statistical analyses, samples were rarified to an equal depth of 1716 sequences per sample (the fewest in a single sample) to minimize effects of sequence depth. Shannon index and ASVs counts were determined using the R package phyloseq [58]. All scripts and data are available in the NCBI Sequence Read Archive (SRA) under accession number PRJNA436030.

Statistical analyses were carried out in two steps. First, differences in bacterial community composition ( $\beta$-diversity) were calculated. To this end, Bray-Curtis similarities were calculated based on rarefied and square-roottransformed ASV abundances. Permutational multivariate analysis of variance (PERMANOVA) [59] was performed using the homonymous routines in PRIMER6 + [60]. PERMANOVA main test and pair-wise tests were performed using treatment as the main factor, allowing for a full permutation of the raw data with Monte-Carlo tests accounting for type III error, where the fixed effects sum to zero with $10^{3}$ permutations. Inter-sample Bray-Curtis distances (i.e. pairwise distances between replicates) are shown as boxplots (Supplementary Fig. S2). Second, amplicon sequence variants (ASVs) that could be used to classify the different treatments with accuracy were determined. Hereafter, these ASVs are termed bioindicators. These were determined using a three-step approach. First, we selected ASVs that were statistically significant for (a) the controls, (b) samples collected 26 days after the beginning of the experiment incubated at $26^{\circ} \mathrm{C}$, and (c) samples collected 26 days after the beginning of the experiment incubated at $30^{\circ} \mathrm{C}$ using a two-way ANOVA. To account for multiple comparisons testing, we used the false discovery rate (FDR) method available in the "lsmeans" $\mathrm{R}$ package. Second, we used a classification based on random forest analysis [61] to evaluate if estimated ASVs classified samples according to their specific treatments. Third, we identified the intersection between the ASVs that were statistically significant and the ones that were most relevant for the random forest classification.

\section{Results}

\section{pBMC consortium selection and assembly}

A total of 30 bacterial isolates were recovered from macerated $P$. damicornis fragments, and 23 from the surrounding seawater. These isolates were screened for potential BMC genes and traits. A total of 44 isolates showed detectable catalase production activity, although only one (Pseudoalteromonas sp.-affiliated strain; 16 S rRNA gene $100 \%$ identity) (Supplementary Table S1) had antagonistic activity against the coral pathogen $V$. coralliilyticus (strain YB; DSM19607). Six isolates were positive for PCR amplification of the nifH gene subunit, 4 for the nirK gene subunit, and 1 for the $d m d \mathrm{~A}$ gene subunit (Supplementary Table S1). A total of 35 isolates were affiliated with Vibrio spp., 14 with Pseudoalteromonas sp., 2 with Halomonas sp., and 2 with Cobetia sp. (genera Halomonas and Cobetia are members of the family Halomonadaceae). All Vibrio sp. isolates were excluded, considering their pathogenic potential to corals [62, 63], and a pBMC consortium was established from the remaining strains. The selection was based on the diversity of genera with morphologically different visual features, in addition to the presence of one or more of the screened pBMC features. Based on this criteria, 5 morphologically different Pseudoalteromonas sp. (out of 14 isolates) obtained from coral tissue were selected, in addition to one representative of each of the other 2 bacterial genera (Cobetia and Halomonas), both obtained from seawater. The Pseudoalteromonas strains displayed rapid growth during the first $6 \mathrm{~h}$ of culture, though all strains in the pBMC consortium displayed similar viable counts, i.e., reaching ca. $1 \times 10^{7}$ cells $\mathrm{mL}^{-1}$ (Supplementary Fig. S3) after $20 \mathrm{~h}$, and a lag phase at $28 \mathrm{~h}$.

\section{PBMC mitigates coral bleaching signs from thermal and pathogen stresses}

The visual appearance of $P$. damicornis coral nubbins, assessed using the Coral Health Chart [53], demonstrated that all treatments maintained at $26^{\circ} \mathrm{C}$ displayed no visible color pigment shift during the 26 days of the experiment. In contrast, all replicates of the CTR treatment raised to $30{ }^{\circ} \mathrm{C}$ (thermal stress) displayed characteristic signs of stress, with a decrease of 1 unit based on the Coral Health Chart [52]. One replicate of the pBMC treatment at $30^{\circ} \mathrm{C}$ also showed a 1-unit decrease, although no visual shifts were detected in 
Vibrio coralliilyticus - BIOLOGICAL CONTROL EXPERIMENT

(A) D2 D3 D4 D5 D6
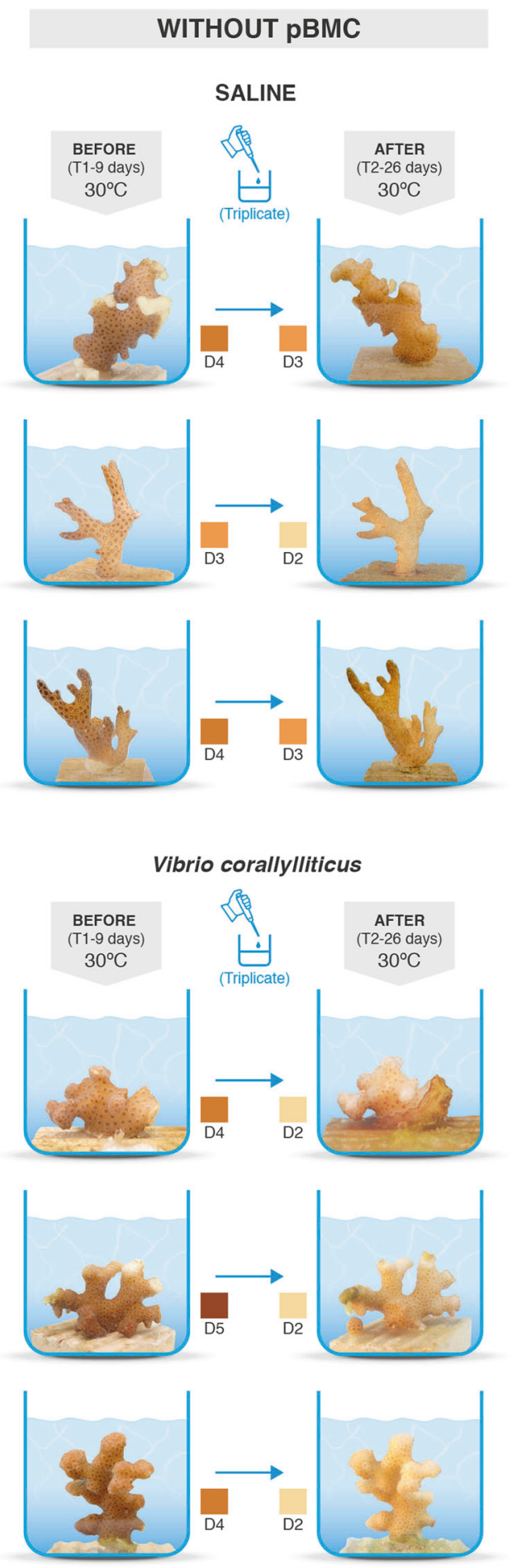

other replicates. The VC-challenged treatment (without pBMC addition) at $30^{\circ} \mathrm{C}$ showed clear signs of bleaching, with decreases of 2-3 units for all replicates (Fig. 2). For the
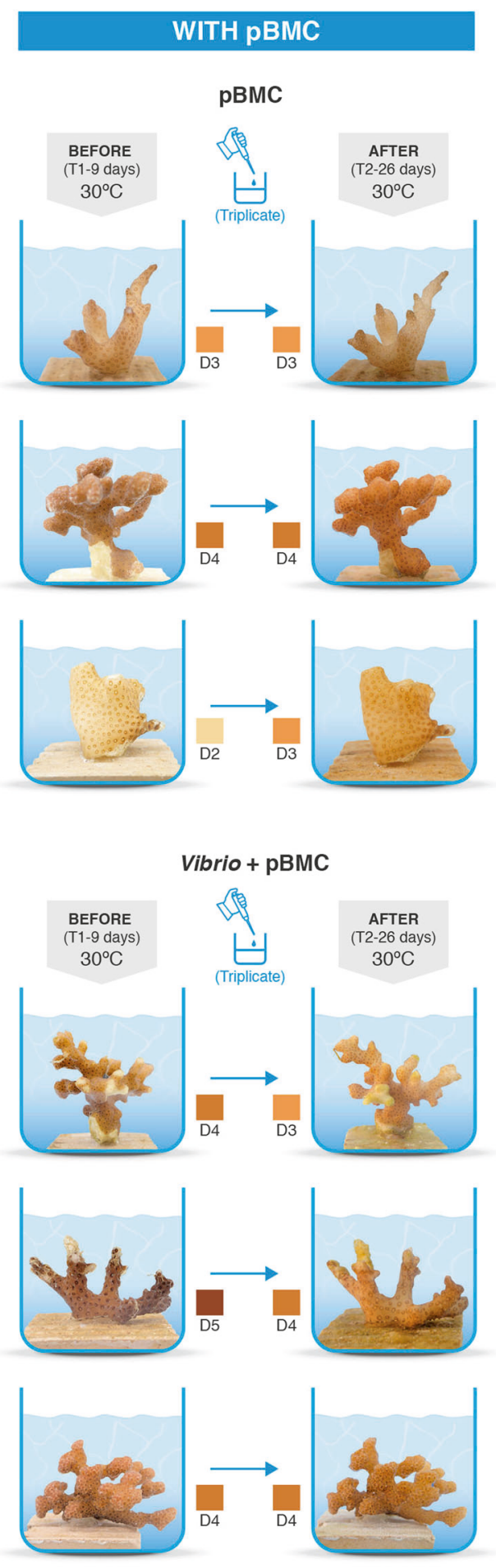

$\mathrm{pBMC}+\mathrm{VC}$-challenged coral treatments, however, only one replicate displayed a small 1-unit decrease, while the remaining replicates showed no signs of bleaching. 
Fig. 2 Comparative photos of the Pocillopora damicornis fragments at the beginning and at the end of the biological control experiment used in the following 4 treatments: saline (control (CTR), no pBMC inoculation) $(n=3)$, pBMC (pBMC inoculation) $(n=3)$, Vibrio coralliilyticus (VC inoculation), $\mathrm{pBMC}+\mathrm{VC}$ (pBMC and VC inoculation). "Before" corresponds to each experiment initial time (Day 9 of experiment corresponds to the initial time control, i.e., peak of temperature and first inoculations were made or started at day 9). "After" corresponds to the end of the experiment (day 26). *original photographs are shown

Regarding the visual shifts observed between treatments at $30{ }^{\circ} \mathrm{C}$, significant differences were detected between those treated with VC compared to those treated with $\mathrm{pBMC}$, between corals treated with $\mathrm{VC}$ and controls, and between corals treated with VC compared to corals treated with pBMC + VC (Student's $t$-test: $P<0.05$ ) (Supplementary Table S3).

Results from the visual response of the coral nubbins across each treatment were confirmed by PAM fluorometry measurements that calculated the $F_{v} / F_{m}$ values indicative of Symbiodinium photosystem function. For corals maintained at $26{ }^{\circ} \mathrm{C}$, including the CTR and pBMC treatments, the $F_{v} /$ $F_{m}$ values were similar, ranging between 0.50 and 0.60 (Fig. 3) and did not present significant differences $(P>$ 0.05). In contrast, all treatments at $30{ }^{\circ} \mathrm{C}$ showed reductions in the $F_{v} / F_{m}$ ratios, with a decrease in the $F_{v} / F_{m}$ ratios of 54, 40,31 , and $20 \%$ respectively for treatments VC, CTR, $\mathrm{pBMC}$, and $\mathrm{pBMC}+\mathrm{VC}$, when compared directly for days 1 and day 26. Similarly reduction of $F_{v} / F_{m}$ ratios of 50, 24, and $12 \%$ for VC, CTR, and pBMC respectively were observed when comparing day 9 (temperature peak and VC inoculation) to day 26 (the end of the experiment) (Fig. 3). Interestingly, the coral nubbins challenged with $\mathrm{VC}$ but also inoculated with $\mathrm{pBMC}(\mathrm{pBMC}+\mathrm{VC})$, at $30^{\circ} \mathrm{C}$, displayed a $6 \%$ increase in the $F_{v} / F_{m}$ ratios between day 9 and 26 (Fig. 3), a $56 \%$ higher mean compared to the treatment exposed solely to VC (ANOVA: F: 14,15 ; df $=1 ; P<0.05$ ) at $30^{\circ} \mathrm{C}$. Significant differences were also observed in comparisons between other treatments at $30^{\circ} \mathrm{C}$, such as higher $F_{v} / F_{m}$ ratios in $\mathrm{pBMC}$ corals compared with $\mathrm{VC}$ (ANOVA: F: 27,69; $\mathrm{df}=1 ; P<0.01$ ), pBMC compared with thermal-stressed controls (ANOVA: F: 8,96 ; $\mathrm{df}=1 ; P$ $<0.05)$, and $\mathrm{pBMC}+\mathrm{VC}$ against thermal-stressed controls (ANOVA: F: 8,43 ; $\mathrm{df}=1 ; P<0.05$ ).

At $30^{\circ} \mathrm{C}$, the abundance of the bacterial $16 \mathrm{~S}$ rRNA gene copies peaked after 26 days for pBMC $\left(1.48 \times 10^{2}-3.26 \times\right.$ $10^{3}$ gene copies $\left.\mathrm{mL}^{-1}\right)$, VC $\left(2.10-4.06 \times 10^{2}\right.$ gene copies $\left.\mathrm{mL}^{-1}\right)$, and $\mathrm{pBMC}+\mathrm{VC}\left(3.84 \times 10^{2}-9.49 \times 10^{3}\right.$ gene copies $\left.\mathrm{mL}^{-1}\right)$ treatments, and there were no significant differences among these treatments $(P>0.05)$. However, when each treatment was compared to the CTR $\left(4.62-8.88 \times 10^{1}\right.$ gene copies $\left.\mathrm{mL}^{-1} ; P<0.01\right)$, at 26 days, significant differences were observed $(P<0.01)$. In addition, copies of the dnaJ gene, specific for vibrios, were detected only in the $\mathrm{VC}$ treatment $\left(6.48 \times 10^{1}-1.42 \times 10^{4}\right.$ gene copies $\left.\mathrm{mL}^{-1}\right)$ at $30^{\circ} \mathrm{C}$, but not in the CTR (no addition of $\mathrm{VC}$ and/or pBMC) and corals inoculated with $\mathrm{pBMC}+\mathrm{VC}$ or any other treatment at $26^{\circ} \mathrm{C}$.

Bacterial community profiling of coral nubbins identified diverse communities associated with the experimental coral fragments, although no significant differences in alphadiversity metrics (ASV counts and Shannon index) were observed across most of the treatments (pairwise $t$-test, $P>$ 0.05, Supplementary Fig. S4). The exception was observed for the pBMC-treatment samples collected after 26 days of incubation at $30{ }^{\circ} \mathrm{C}$, which displayed ASV counts lower

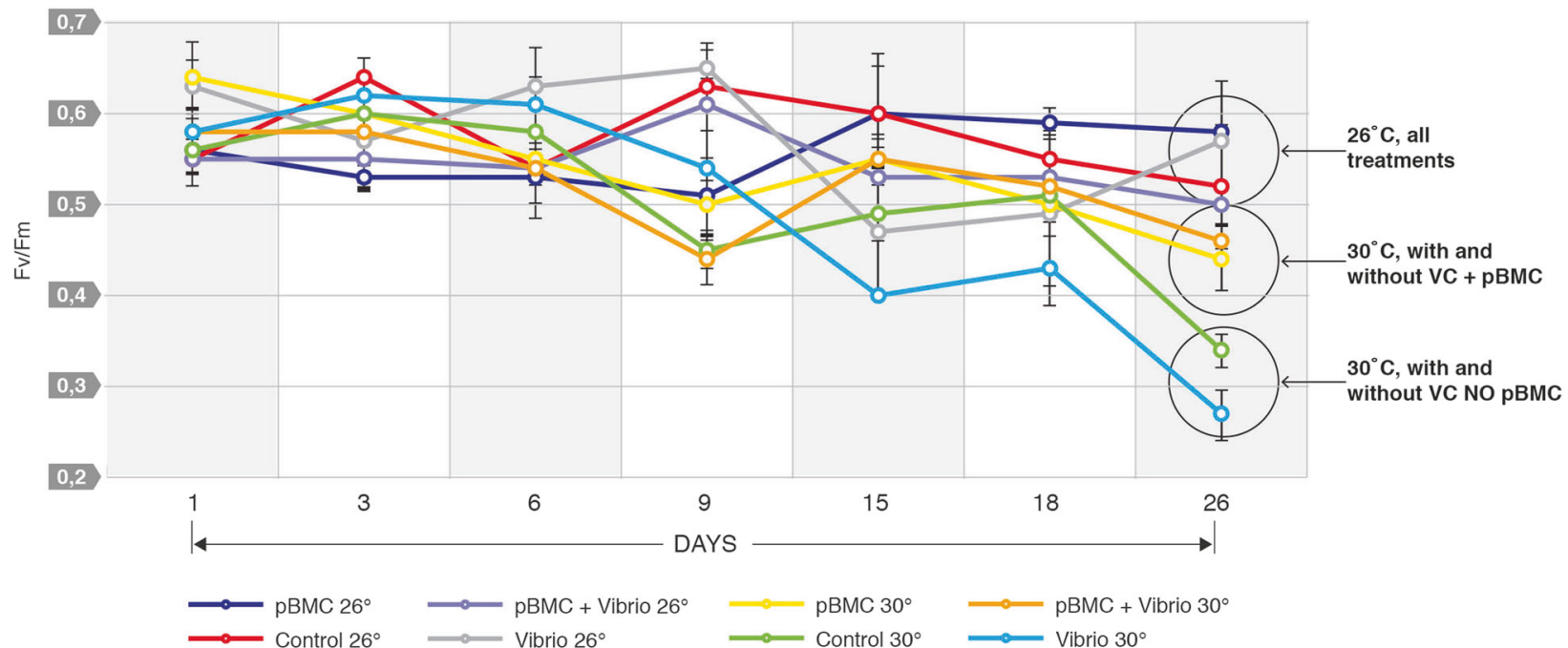

Fig. 3 Measurements of $F_{v} / F_{m}$ in Pocillopora damicornis at $30{ }^{\circ} \mathrm{C}$ and $26^{\circ} \mathrm{C}$ during 26 days of experiment, with the following treatments: control, no inoculation (CTR), pBMC (pBMC consortium inoculation), VC (Vibrio coralliilyticus inoculation), pBMC + VC (pBMC consortium and Vibrio coralliilyticus inoculation) control (CTR) $(n=3)$ 

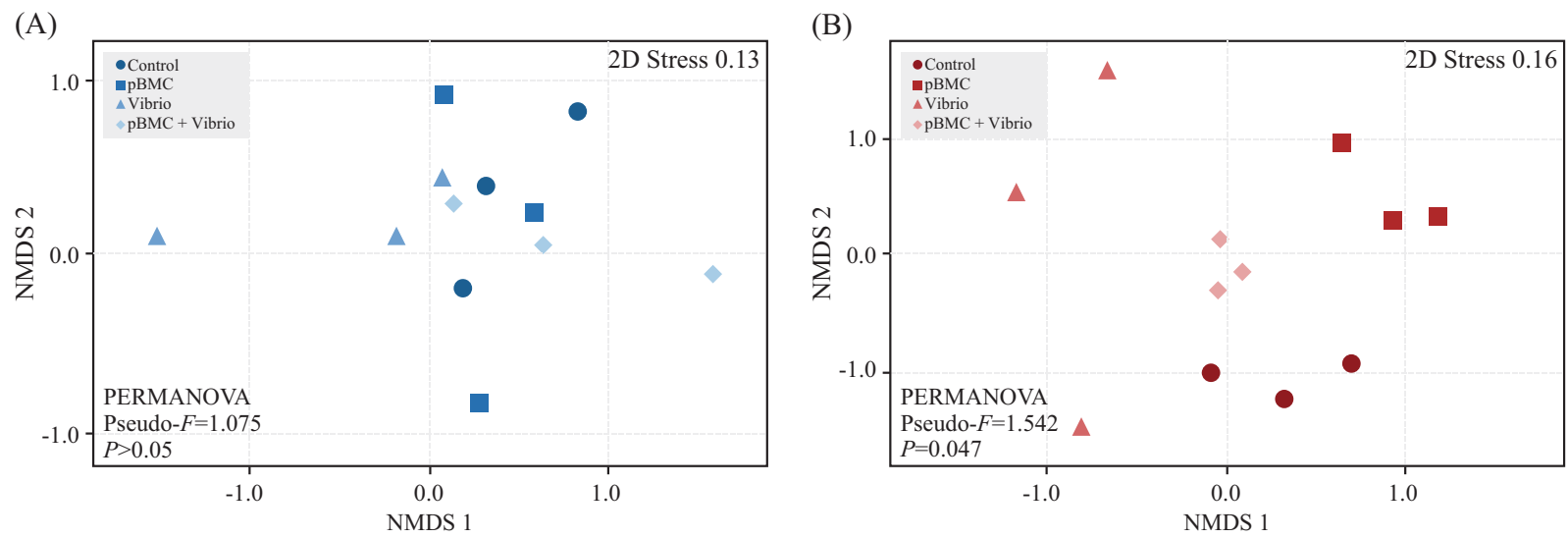

Fig. 4 NMDS plots of Pocillopora damicornis microbiome at $26^{\circ} \mathrm{C}(\mathbf{a})$ and $30^{\circ} \mathrm{C}(\mathbf{b})$, at day 26 , based on high-throughput sequencing data $(n=$ 3). Statistics are provided as inset panels

than the corresponding $\mathrm{pBMC}+\mathrm{VC}$ treatment (pairwise $t$ test, $P<0.05$, Supplementary Fig. S4). In addition, no clear separation of treatments was observed when comparing all samples from the different temperatures collected 26 days after the beginning of the experiment (Supplementary Fig. S5). To confirm these results, no treatment pair-wise statistical differences were detected (PERMANOVA, $10^{3}$ permutations, $P>0.05$ ) across treatments and between samples incubated at $26^{\circ} \mathrm{C}$ or $30^{\circ} \mathrm{C}$ (Supplementary Table S5). Therefore, intra-sample variability NMDS plots were generated separately for corals incubated for 26 days at $26^{\circ} \mathrm{C}$ or $30^{\circ} \mathrm{C}$ (Fig. 4). For samples from day 26 at $26{ }^{\circ} \mathrm{C}$ (Fig. 4a), no significant differences were observed between the distances from samples inoculated with $\mathrm{pBMC}+\mathrm{VC}$ or only with VC (PERMANOVA main test; Pseudo- $F=$ $1.075, P>0.05$, see also Supplementary Table S6). At $30^{\circ}$ $\mathrm{C}$, a significant difference across treatments was observed 26 days after the beginning of the experiment (PERMANOVA main test; Pseudo- $F=1.542, P=0.047$, see also Supplementary Table S6). In addition, for treatments at $30^{\circ}$ $\mathrm{C}, \mathrm{pBMC}+\mathrm{VC}$ and $\mathrm{VC}$ showed significantly $(P<0.05)$ lower and higher inter-sample dissimilarities, respectively, when compared with control and pBMC treatments (Supplementary Fig. S2). No significant clustering of replicate samples $(P>0.28$, Supplementary Table S4) was observed for treatment or sampling time (days 1,9 , and 26) for corals that were not inoculated with pBMC and/or VC at $26^{\circ} \mathrm{C}$ or $30^{\circ} \mathrm{C}$ (Supplementary Fig. S6). In contrast, for samples incubated for 26 days at $26^{\circ} \mathrm{C}$ (Supplementary Fig. S7; $P>$ 0.13 ; Supplementary Table S6) and at $30^{\circ} \mathrm{C}$ (Supplementary Fig. S8; $P<0.05$; Supplementary Table S6), a clear clustering of replicates from $\mathrm{pBMC}$ - and $\mathrm{pBMC}+\mathrm{VC}$ inoculated corals was observed by Bray-Curtis distances.

To determine which ASVs correlated with the partial mitigation of bleaching signs for corals at the end of the $30^{\circ} \mathrm{C}$ experiment, the ASVs that were significantly different in at least one of the treatments were detected in a 2-way ANOVA and $P$-values adjusted using the false discovery rate method, where inoculations of $\mathrm{pBMC}$ and $\mathrm{VC}$ were used as factors. A total of $30 \mathrm{SVs}$ were significantly different in at least one treatment $(P<0.05)$ (Supplementary Fig. S8, Supplementary Table S7). In contrast, only 10 ASVs were significant in at least one treatment for samples incubated at $26^{\circ} \mathrm{C}$ after 26 days of the experiment $(P<$ 0.05) (Supplementary Fig. S7, Supplementary Table S8). The results of a two-way ANOVA with multiple correction testing for each sample group (control, $26^{\circ} \mathrm{C}$ and $30^{\circ} \mathrm{C}$ ) under different treatments are shown in Supplementary tables S9, S10, and S11, respectively. Further, our random forest analyze results demonstrated that, at the end of the experiment (day 26) samples incubated at $30{ }^{\circ} \mathrm{C}$ with $0 \%$ error, while $\sim 42 \%$ of classification errors were detected for samples incubated at $26^{\circ} \mathrm{C}$ (Supplementary Table S12). The mean decrease Gini score obtained in the random forest analysis for samples incubated at $30^{\circ} \mathrm{C}$ after 26 days of the experiment showed that 24 ASVs had considerably higher scores than all others for classifying the different treatments with accuracy (Supplementary Fig. S9). To determine the bioindicators, we intersected the 30 ASVs that were statistically significant and 24 most relevant for the classification of samples after 26 days of the experiment at $30^{\circ} \mathrm{C}$ (Fig. 5). A total of 23 ASVs were classified as bioindicators, and further separated into five groups (Fig. 5). From those ASVs that showed significant differences in the interaction between pBMC and pBMC + VC, an ASV classified as Cobetia was the most dominant in those samples inoculated only with pBMC, followed by an ASV classified as Oceanobacillus (a box plot with relative abundances of these ASVs is shown in Supplementary Fig. S10-12). Most of the ASVs that were classified as bioindicators belonged to Alphaproteobacteria (9 ASVs), followed by Planctomycetes (8 ASVs) (Fig. 5). ASVs belonging to Ruegeria and 


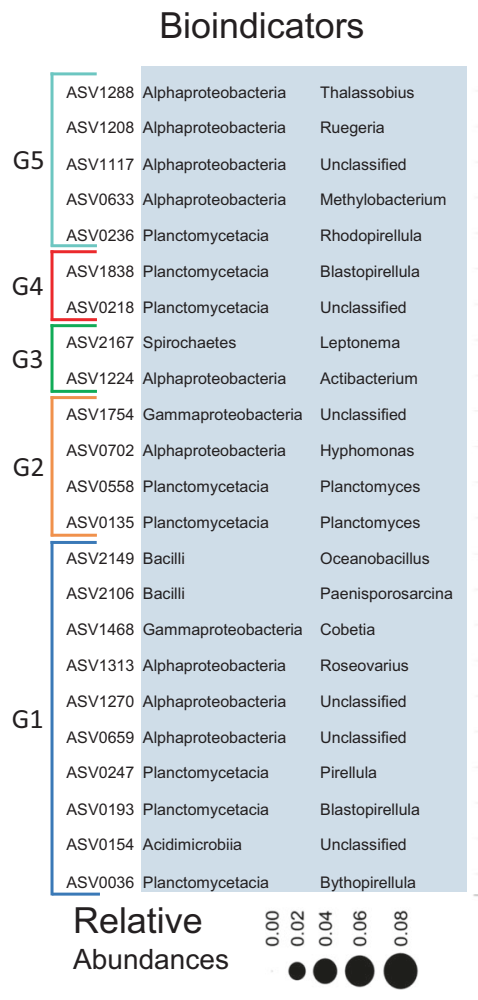

Fig. 5 Relative abundance distribution of ASVs used as bioindicators in the different treatments (Controls, pBMC, pBMC $+\mathrm{VC}$ and VC) per sample. The size of the circles represent the relative abundances. We added colors to ASV relative abundances belonging to the same treatments. Class and genus of each ASVs are also shown in this figure. We grouped the ASVs in 5 different groups depending on how the different ASVs showed statistic differences $(P<0.5)$ in a False Discovery Rate test performed after a two way ANOVA using

Thalassobios were the most dominant ASVs present in the VC treatment (Fig. 5, Supplementary Fig. S10).

\section{Discussion}

Recent assessments have documented declines in coral cover driven by both local and global anthropogenic impacts, including increased frequency of large-scale bleaching events $[7,8]$. While the priority actions to protect coral-reef ecosystems should focus on minimizing global changes and $\mathrm{CO}_{2}$ emissions [8], other palliative actions are required to stem or even reverse these declines. Currently, there is no feasible treatment that can minimize temperature bleaching and/or disease impact on corals in the field at reef scale. Current research efforts have been focused on restoring local populations through propagation and gardening approaches or selecting resistant coral communities (i.e., assisted breeding, assisted translocation, and human-assisted evolution) [11, 13, 64]. The development of protective management or treatments to be applied in situ, to build or enhance the resistance and/or resilience of corals in the field represents a useful complementary strategy.

This study presents the first attempt to extrapolate the well-established use of bacterial consortia [65-67] to protect or improve the health of corals. It should be noted that this experimental study used artificial seawater in aquaria, which may influence the coral microbiomes when compared to those in natural settings. The results generated from a controlled and replicated aquarium experiment demonstrated the ability of a selected pBMC consortium to partially mitigate coral bleaching induced through both temperature and putative pathogen challenge, proving the concepts that (a) it is possible to manipulate the coral microbiome and (b) this manipulation can influence the coral health status. The inoculated pBMC consortium increased coral resistance to bleaching, as assessed through visual pigment levels and Symbiodinium photochemical efficiency. These improvements in coral-bleaching metrics were observed in pBMC-inoculated corals at $30^{\circ} \mathrm{C}$, in contrast to controls without pBMC addition, which displayed strong bleaching signs, as indicated by significantly 
lower photopigment contents and $F_{v} / F_{m}$ ratios. Even for corals challenged with the pathogen $V$. coralliilyticus, treatments without pBMC addition bleached, while treatments in which the pBMCs were added 1 day after VC challenge displayed no signs of bleaching. This physiological response indicates that the pBMC inoculation partially mitigated the bleaching process, both when corals were subjected to a temperature stress alone and when they were also challenged with a bacterial pathogen. Considering that coral mortality levels caused by bleaching depend on the intensity and extent of the seawater-temperature event and the ability of the holobiont to resist other ancillary challenges such as microbial infections [68], any approach that increases coral resistance represents an important strategy that can benefit coral reef ecosystems.

The quantification of total bacteria and $V$. coralliilyticus abundances in coral nubbins demonstrated that $V$. coralliilyticus was detected only in treatments without the added pBMC consortium. For example, $6.48 \times 10^{1}-1.42 \times$ $10^{4}$ dnaJ gene copies $\mathrm{mL}^{-1}$ were detected from VC-treated corals, while no gene copies were detected in any other treatments, including $\mathrm{pBMC}+\mathrm{VC}$, suggesting biological control of $\mathrm{VC}$ by the inoculated pBMC consortium. The importance of manipulating the coral microbiome and tracking coral health was recently highlighted by Welsh et al[32]., who demonstrated the predation of $V$. coralliilyticus by Halobacteriovorax, and that specific predator (s) can control "alien" coral-opportunistic pathogens. Biocontrol of microbial diseases has been used widely across many environments and for different organisms [69-71], but this approach is still a little-explored concept for coral protection. Our data support the potential usefulness of this approach, by indicating that coral health can be improved through biological control of the inoculated $V$. coralliilyticus pathogen. Different mechanisms are likely to be involved in this process, including the direct antagonistic activity of one or more of the pBMC members, or indirect niche colonization by the pBMCs, which exclude $V$. coralliilyticus. The experimental manipulation may have also promoted shifts in the coral microbiome, thus excluding other opportunistic pathogens or allowing the establishment of other beneficial components, thereby indirectly making corals less vulnerable to bacterial pathogens. Clustering of the coral-associated microbiomes was observed for inoculated corals at $30^{\circ} \mathrm{C}$, and consistent bacterial bioindicators of the different treatments were detected only at $30^{\circ} \mathrm{C}$, indicating that these community shifts were the direct result of the microbiome manipulation in corals under stress, although the exact mechanisms triggering the changes still need to be explored.

The coral microbiomes of the $\mathrm{VC}$ treatment at $30^{\circ} \mathrm{C}$, which displayed signs of bleaching, also showed more dispersed community structure between replicates, when compared with control and pBMC-inoculated corals, after 26 days of the experiment. This pattern aligns with the Anna Karenina principle (AKP), proposed by Zaneveld and collaborators [72], in which microbiomes from stressed organisms, in this case, those inoculated with a pathogen, vary more than those associated with "healthy" hosts. The AKP also reinforces the putative benefits that pBMC manipulations may have in influencing the coral host microbiome, i.e., providing greater community stability and therefore minimizing stochastic shifts in the face of stress (es). Following the AKP prediction, it is important to note that coral samples inoculated with $\mathrm{VC}+\mathrm{pBMC}$ had lower Bray-Curtis dissimilarity than controls or corals inoculated with pBMC. Interestingly, this result aligns with the physiological proxy data, where $\mathrm{VC}+\mathrm{pBMC}$ samples had higher $\mathrm{F} v / \mathrm{Fm}$ values than that of $\mathrm{pBMC}$. While tempting to speculate that the inoculation of VC might have favored the establishment of pBMC, for instance through a disturbancemediated effect, we cannot conclusively confirm this with the data obtained in the current study. Understanding the influence of the pBMC community at the cellular level is an important next step to elucidate this and other questions. It is currently not known if the pBMCs colonize the host and help to establish a healthy microbiome, thereby preventing a random assembly of the community that could be shifted easily by opportunistic and potentially pathogenic members, i.e., the pathobiome [31]. An alternative explanation would consist of pBMCs providing an additional source of nutrition through heterotrophy and stimulated microbial loops that sustain the corals and prevent bleaching, although Cobetia sp. being selected as a bioindicator of pBMC treatment at $30^{\circ} \mathrm{C}$ suggests that at least this strain was not used primarily as a nutrition source.

This pBMC-inoculated strain, Cobetia sp., was a dominant member of the CTR microbiome $\left(26^{\circ} \mathrm{C}\right.$ treatment and sampled at days 1,9 , and 26), and a selected bioindicator and high-abundance group correlated with pBMC- and pBMC + VC-inoculated corals at $30^{\circ} \mathrm{C}$. However, Cobetiaaffiliated sequences were not retrieved from stressed corals (CTR and VC treatments at $30^{\circ} \mathrm{C}$ ), suggesting that Cobetia may not only be sensitive to the applied stress but also have some role in mitigating the temperature and pathogen challenge effects. The bioaugmentation of the surroundings with native pBMCs, as successfully demonstrated by the Cobetia inoculation, during events of environmental stress would increase the chances for the uptake and establishment of beneficial (or at least non-pathogenic) microorganisms, instead of pathogen selection and establishment. Once the environmental-stress conditions return to standard conditions, i.e., without the acute selective pressure, the holobiont may return to the original stable state. For example, during a 
bleaching event, the microbiome of A. millepora colonies was shown to shift as the colonies bleached with increasing temperature, although post-bleaching the microbiome returned to a profile similar to the pre-bleaching microbiome [73]. These observations are again consistent with Zaneveld and colleagues [72] in their parallel to Tolstoy's "War and Peace".

Other specific bioindicator taxa were consistently selected across treatments incubated at $30^{\circ} \mathrm{C}$, with, for example, the presence of Ruegeria sp.-affiliated sequences correlated with VC-inoculated corals. Ruegeria species have been previously associated with Yellow Band Disease (YBD), with a consortium of Vibrio species implicated in causation [74]. Roseovarius sp. and Thalassobius sp. groups, both previously associated with coral disease and stress [75-77], were also selected as bioindicators and were detected in VC-inoculated corals only at $30^{\circ} \mathrm{C}$, likely opportunistically taking advantage of compromised coral hosts. In contrast, Oceanobacillus sp.-affiliated sequences were associated with pBMC-inoculated corals, with or without concomitant inoculation of VC, while Paenisporosarcina sp. were detected only in pBMC-inoculated corals not challenged with VC. The microbial diversity and the relationships between key microbial players may be differently affected by the two stressor agents [78-81]. Ultimately, the beneficial manipulation of key microorganisms may result in a more stable microbiome, which is less vulnerable to microbial invasion [56, 82-84].

This study successfully demonstrated the potential of a pBMC consortium to partially prevent bleaching in temperature- and bacteria-challenged corals over a short-term aquarium experiment. We suggest that this consortium can be considered not merely as putative BMC consortium (i.e., a pBMC)but as a BMC consortium (without the need for the putative modifier), since a selection of sequences retrieved from our experimental system displayed high identity with the strains incorporated as BMC inoculates (Supplementary Fig. S13). Scaling up our experimental system by including more replicates is required to further validate these findings, and information on the mechanism(s) by which this BMC consortium as a whole, and individual strains, promoted coral resistance is currently lacking. However, at least one of the inoculated strains (Cobetia sp.) was an abundant bioindicator of the BMC inoculation in the coral microbiomes at $30^{\circ} \mathrm{C}$ at the end of the experiment, suggesting some level of competitiveness and potential niche establishment. In contrast, Pseudoaltermonas sp. and Halomonas sp.-affiliated sequences were not detected as bioindicators of the BMC treatments at the end of the experiment, even though the corals were inoculated with 5 strains belonging to the genus Pseudoalteromonas, indicating that these strains may not have been able to establish as part of the dominant coral microbiome. It is possible, however, that such strains may have indirect beneficial effects by stimulating other microbiome community members, including the establishment of the Cobetia marina strain. There is still much to understand about the ecological intricacies of this system in the context of the existing members of the coral microbiome. To further explore the potential of pBMC and pBMC consortia, new approaches for the selection and inoculation of such consortia into the coral holobiont need to be developed. Future studies should also focus on the omics analyses and in situ visualization, to elucidate the interactions between BMCs and the host and other microbiome partners, and establish the mechanisms by which they improve coral health. Such studies will elucidate if the competitive BMCs provide direct benefits to the corals or if the inoculated strains support other key symbiotic populations within the coral microbiome during adverse environmental conditions. Of critical importance, this study demonstrates that the addition of BMC consortium is a potentially promising approach to improve coral fitness. This approach can also contribute to a better understanding of the symbiotic cellular interactions that are essential for contributing to the resistance and resilience in coral populations faced with increasing environmental pressures.

Acknowledgements We thank Madhi Moradi, Cassia Jonck, Cátia Barbosa, and Alexandre Rosado for logistical support during the mesocosm experiment and helpful suggestions and discussion. We also thank Fabiano Thompson for providing Vibrio coralliilyticus cells for previous pilot experiments, and Leonardo Carvalho, Igor Albergaria, Marcelo Cunha and Robson Aragão for providing coral colonies. We thank the Graduate Programs of Science (Microbiology) and Vegetal Biotechnology and Bioprocess Engineering (PBV)/Federal Univerity of Rio de Janeiro, the National Council for Scientific and Technological Development $(\mathrm{CNPq})$, the National Council for the Improvement of Higher Education (CAPES), and the Carlos Chagas Filho Foundation for Research Support of Rio de Janeiro State (FAPERJ) for their support. J.A. Eisen and G. Jospin were supported by a grant from the Gordon and Betty Moore Foundation.

Authors' contributions Study conception and design: Rosado P., Duarte G., Eisen J., Bourne D., and Peixoto R.S.; Acquisition of data (conducting of experiments): Rosado P., Leite D.C.A., Duarte G., Peixoto R.S.; Analyses and interpretation of data: Rosado P., Leite D. C.A., Duarte G., Jospin G., Eisen J., Saraiva J., Rocha U., DiniAndreote F., Bourne D., Peixoto R.S.; Drafting of the manuscript: Peixoto R.S., Bourne D.; Critical revision by all authors. Financial support: Peixoto, R.S.

Funding This study was supported by the National Council for Scientific and Technological Development (CNPq), the National Council for the Improvement of Higher Education (CAPES) and the Carlos Chagas Filho Foundation for Research Support of Rio de Janeiro State (FAPERJ).

\section{Compliance with ethical standards}

Conflict of interest The authors declare that they have no conflict of interest. 
Open Access This article is licensed under a Creative Commons Attribution 4.0 International License, which permits use, sharing, adaptation, distribution and reproduction in any medium or format, as long as you give appropriate credit to the original author(s) and the source, provide a link to the Creative Commons license, and indicate if changes were made. The images or other third party material in this article are included in the article's Creative Commons license, unless indicated otherwise in a credit line to the material. If material is not included in the article's Creative Commons license and your intended use is not permitted by statutory regulation or exceeds the permitted use, you will need to obtain permission directly from the copyright holder. To view a copy of this license, visit http://creativecommons. org/licenses/by/4.0/.

\section{References}

1. Knowlton N, Jackson JBC. The ecology of coral reefs. In: Bertness MD, Gaines SD, Hay ME (eds). Marine Community Ecology. Sinauer Associates: Sunderland, MA, USA; 2001. p. 395422.

2. Barott KL, Rodriguez-Brito B, Janouškovec J, Marhaver KL, Smith JE, Keeling P, et al. Microbial diversity associated with four functional groups of benthic reef algae and the reef-building coral Montastraea annularis. Environ Microbiol. 2011;13:1192204.

3. Doney SC, Ruckelshaus M, Duffy JM, Barry JP, Chan F, English $\mathrm{CA}$, et al. Climate change impacts on marine ecosystems. Annu Rev Mar Sci. 2012;4:11-37.

4. Bourne DG, Morrow KM, Webster NS. Coral holobionts: insights into the coral microbiome: underpinning the health and resilience of reef ecosystems. Annu Rev Microbiol. 2016;70:317-40.

5. Ainsworth TD, Fordyce AJ, Camp EF. The other microeukaryotes of the coral reef microbiome. Trends Microbiol. 2017;25:980-91.

6. Kwiatkowski L, Cox P, Halloran PR, Mumby PJ, Wiltshire AJ. Coral bleaching under unconventional scenarios of climate warming and ocean acidification. Nat Clim Change. 2015;5:77781.

7. Hughes TP, Kerry JT, Álvarez-Noriega M, Álvarez-Romero JG, Anderson KD, Baird AH, et al. Global warming and recurrent mass bleaching of corals. Nature. 2017;543:373-7.

8. Hughes TP, Anderson KD, Connolly SR, Heron SF, Kerry JT, Lough JM, et al. Spatial and temporal patterns of mass bleaching of corals in the Anthropocene. Science. 2018;359:80-3.

9. Hoegh-Guldberg O. Climate change, coral bleaching and the future of the world's coral reefs. Mar Freshwater Res. 1999;50:839-66.

10. Omori M. Degradation and restoration of coral reefs: experience in Okinawa, Japan. Mar Biol Res. 2010;7:3-12.

11. Young CN, Schopmeyer S, Lirman D. A review of reef restoration and coral propagation using the threatened genus Acropora in the Caribbean and western Atlantic. Bull Mar Sci. 2012;88:1075-98.

12. Rinkevich B. Rebuilding coral reefs: does active reef restoration lead to sustainable reefs? Curr Opin Environ Sustain. 2014;7:2836.

13. Van Oppen MJH, Oliver JK, Putnam HM, Gates RD. Building coral reef resilience through assisted evolution. Proc Natl Acad Sci USA. 2015;112:2307-13.

14. Foo JL, Ling H, Lee YS, Chang MW. Microbiome engineering: current applications and its future. Biotechnol. J. 2017;12:1600099.

15. Hartman K, van der Heijden MGA, Wittwer RA, Banerjee S, Walser JC, Schlaeppi K. Cropping practices manipulate abundance patterns of root and soil microbiome members paving the way to smart farming. Microbiome. 2018;6:14 https://doi.org/10. 1186/s40168-017-0389-9
16. Wolfert S, Ge L, Verdouw C, Bogaardt MJ. Big data in smart farminga review. Agric Syst. 2017;153:69-80. https://doi.org/10. 1016/j.agsy.2017.01.023

17. Dinsdale EA, Edwards RA, Hall D, Angly F, Breitbart M, Brulc $\mathrm{JM}$, et al. Functional metagenomic profiling of nine biomes. Nature. 2008;452:629-32.

18. Garren M, Azam F. New directions in coral reef microbial ecology. Environ Microbiol. 2012;14:833-44.

19. Thompson JR, Rivera HE, Closek CJ, Medina M. Microbes in the coral holobiont: partners through evolution, development, and ecological interactions. Front Cell Infect Microbiol. 2014;4:176.

20. Eilenberg J, Hajek A, Lomer C. Suggestions for unifying the terminology in biological control. BioControl. 2001;46:387-400.

21. Kloepper JW, Schroth M. Plant growth-promoting rhizobacteria on radishes. In Proceedings of the 4th International Conference on Plant Pathogenic Bacteria. Tours: Gilbert-Clarey; 1978;2: 879-82.

22. Gotz M, Gomes NC, Dratwinski A, Costa R, Berg G, Peixoto R, et al. Survival of gfp-tagged antagonistic bacteria in the rhizosphere of tomato plants and their effects on the indigenous bacterial community. FEMS Microbiol Ecol. 2006;56:207-18.

23. Carmo FL, Santos HF, Martins EF, van Elsas JD, Rosado AS, Peixoto RS. Bacterial structure and characterization of plant growth promoting and oil degrading bacteria from the rhizospheres of mangrove plants. J Microbiol. 2011;49:53543.

24. Beneduzi A, Ambrosini A, Passaglia L. Plant growth-promoting rhizobacteria (PGPR): their potential as antagonists and biocontrol agents. Genet Mol Biol. 2012;35:1044-51.

25. Vejan P, Abdullah R, Khadiran T, Ismail S, Boyce AN. Role of plant growth promoting rhizobacteria in agricultural sustainability - a review. Molecules. 2016;21:573.

26. Grover S, Rashmi HM, Srivastava AK, Batish VK. Probiotics for human health - new innovations and emerging trends. Gut Pathog. 2012;4:15.

27. Santos HF, Carmo FL, Paes JES, Rosado AS, Peixoto RS. Bioremediation of mangroves impacted by petroleum. Water Air Soil Pollut. 2011;216:329-50.

28. Santos HF, Duarte GAS, Rachid CT, Chaloub RM, Calderon EN, Marangoni LFB, et al. Impact of oil spills on coral reefs can be reduced by bioremediation using probiotic microbiota. Sci Rep. 2015;5:18268.

29. Peixoto RS, Rosado PM, Leite DCA, Rosado AS, Bourne DG. Beneficial microorganisms for corals (BMC): proposed mechanisms for coral health and resilience. Front Microbiol. 2017;8:341.

30. Damjanovic K, Blackall L, Webster N, van Oppen M. The contribution of microbial biotechnology to mitigating coral reef degradation. Microb Biotechnol. 2017;10:1236-43.

31. Sweet MJ, Ramsey A, Bulling MT. Designer reefs and coral probiotics: great concepts but are they good practice? Biodiversity, 2017;18:19-22.

32. Welsh RM, Rosales SM, Zaneveld JR, Payet JP, McMinds R, Hubbs SL, et al. Alien vs. predator: bacterial challenge alters coral microbiomes unless controlled by Halobacteriovorax predators. PeerJ. 2017;5:e3315.

33. Burriesci MS, Raab TK, Pringle JR. Evidence that glucose is the major transferred metabolite in dinoflagellate-cnidarian symbiosis. J Exp Biol. 2012;215:3467-77.

34. Davy SK, Allemand D, Weis VM. Cell biology of cnidariandinoflagellate symbiosis. Microbiol Mol Biol Rev. 2012;76:22961.

35. Tremblay P, Grover R, Maguer JF, Legendre L, Ferrier-Pages C. Autotrophic carbon budget in coral tissue: a new ${ }^{13} \mathrm{C}$-based model of photosynthate translocation. J Exp Biol. 2012;215:1384-93.

36. Alagely A, Krediet CJ, Ritchie KB, Teplitski M. Signalingmediated cross-talk modulates swarming and biofilm formation in a coral pathogen Serratia marcescens. ISME J. 2011;5:1609-20. 
37. Kvennefors ECE, Sampayo E, Kerr C, Vieira G, Roff G, Barnes AC. Regulation of bacterial communities through antimicrobial activity by the coral holobiont. Microb Ecol. 2012;63:605-18.

38. Raina J, Tapiolas D, Motti CA, Foret S, Seemann T, Tebben J, et al. Isolation of an antimicrobial compound produced by bacteria associated with reef-building corals. PeerJ. 2016;4:e2275.

39. Webster NS, Reusch T. Microbial contributions to the persistence of coral reefs. ISME J. 2017;11:2167-74.

40. Ben-Haim Y, Rosenberg E. A novel Vibrio sp. pathogen of the coral Pocillopora damicornis. Mar Biol. 2002;141:47-55.

41. Ben-Haim Y, Zicherman-Keren M, Rosenberg E. Temperatureregulated bleaching and lysis of the coral Pocillopora damicornis by the novel pathogen Vibrio coralliilyticus. Appl Environ Microbiol. 2003;69:4236-42.

42. Giambiagi-Demarval M, Mafra MA, Penido EGC, Bastos MCF. Distinct groups of plasmids correlated with bacteriocin production in Staphylococcus aureus. J Gen Microbiol. 1990;136:1591-9.

43. Taylor WI, Achanzar D. Catalase test as an aid to the identification of Enterobacteriaceae. Appl Microbiol. 1972;24:58-61.

44. Poly F, Monrozier L, Bally R. Improvement in the RFLP procedure for studying the diversity of nifH genes in communities of nitrogen fixers in soil. Res Microbiol. 2001;152:95-103.

45. Hallin S, Lindgren P. PCR detection of genes encoding nitrite reductase in denitrifying bacteria. Appl Environ Microbiol. 1999;65:1652-57.

46. Varaljay V, Howard E, Sun S, Moran M. Deep sequencing of a dimethylsulfoniopropionate-degrading gene $(d m d A)$ by using PCR primer pairs designed on the basis of marine metagenomic data. Appl Environ Microbiol. 2010;76:609-17.

47. Lane D. Nucleic acid techniques in bacterial systematics, In: Stackebrandt E, Goodfellow M, editors. 16S/23S rRNA sequencing. John Wiley and Sons: New York, NY; 1991. p. 115-175.

48. Cole SE, LaRiviere FJ, Merrikh CN, Moore MJ. A convergence of rRNA and mRNA quality control pathways revealed by mechanistic analysis of nonfunctional rRNA decay. Mol Cell. 2009;34:440-50.

49. Hall T. BioEdit: a user-friendly biological sequence alignment editor and analysis program for Windows 95/98/NT. Nucleic Acids Symp Ser. 1999;41:95-8.

50. Altschul S, Gish W, Miller W, Myers EW, Lipman DJ. Basic local alignment search tool. J Mol Biol. 1990;215:403-10.

51. Miles AA, Misra SS, Irwin JO. The estimation of the bactericidal power of the blood. J Hyg. 1938;38:732-49.

52. Siebeck UE, Marshall NJ, Klueter A, Hoegh-Guldberg O. Monitoring coral bleaching using a color reference card. Coral Reefs. 2006;25:453-60.

53. Horvath KM, Castillo KD, Armstrong P, Westfield ID, Courtney T, Ries JB. Next-century ocean acidification and warming both reduce calcification rate, but only acidification alters skeletal morphology of reef-building coral Siderastrea siderea. Sci Rep. 2016;6:29613.

54. Ralph PJ, Schreiber U, Gademann R, Kuhl M, Larkum AWD. Coral photobiology studied with a new imaging pulse amplitude modulated fluorometer. J Phycol. 2005;41:335-42.

55. Pollock FJ, Morris PJ, Willis BL, Bourne DG. Detection and quantification of the coral pathogen Vibrio coralliilyticus by realtime PCR with TaqMan fluorescent probes. Appl Environ Microbiol. 2010;76:5282-6.

56. Muyzer G, De Waal EC, Uitterlinden AG. Profiling of complex microbial populations by denaturing gradient gel electrophoresis analysis of polymerase chain reaction-amplified genes coding for 16S rRNA. Appl Environ Microbiol. 1993;59:695-700.

57. Leite DCA, Salles JF, Calderon EN, van Elsas JD, Peixoto RS. Specific plasmid patterns and high rates of bacterial co-occurrence within the coral holobiont. Ecol Evol. 2018;8:1818-32.
58. McMurdie PJ, Holmes S. phyloseq: an R Package for reproducible interactive analysis and graphics of microbiome census data. PLoS ONE. 2013;8:e61217.

59. Anderson MJ. A new method for non-parametric multivariate analysis of variance. Austral Ecol. 2001;26:32-46.

60. Clarke K, Gorley R. PRIMER, 6th edn. PRIMER-E Ltd: Plymouth, UK; 2006.

61. Liaw A, Wiener M. Classification and regression by randomForest. R News. 2002;2-3:18-22.

62. Vidal-Dupiol J, Ladrière O, Meistertzheim AL, Fouré L, Adjeroud M, Mitta G. Physiological responses of the scleractinian coral Pocillopora damicornis to bacterial stress from Vibrio coralliilyticus. J Exp Biol. 2011a;214:1533-45.

63. Vidal-Dupiol J, Ladrière O, Destoumieux-Garzón D, Sautière PE, Meistertzheim AL, Tambutté E, et al. Innate immune responses of a scleractinian coral to vibriosis. J Biol Chem. 2011b;286:2268898.

64. van Oppen MJH, Gates RD, Blackall LL, Cantin N, Chakravarti LJ, Chan WY, et al. Shifting paradigms in restoration of the world's coral reefs. Glob Change Biol. 2017;23:3437-48.

65. Trujillo EE. History and success of plant pathogens for biological control of introduced weeds in Hawaii. Biol Control. 2005;33:113-22.

66. Nagpal R, Kumar A, Kumar M, Behare PV, Jain S, Yadav H. Probiotics, their health benefits and applications for developing healthier foods: a review. FEMS Microbiol Lett. 2012;334:1-15.

67. Decamp O, Moriarty DJW, Lavens P. Probiotics for shrimp larviculture: review of field data from Asia and Latin America. Aquacult Res. 2008;39:334-8.

68. Ainsworth TD, Heron SF, Ortiz JC, Mumby PJ, Grech A, Ogawa $\mathrm{D}$, et al. Climate change disables coral bleaching protection on the Great Barrier Reef. Science. 2016;352:338-42.

69. Verschuere L, Rombaut G, Sorgeloos P, Verstraete W. Probiotic bacteria as biological control agents in aquaculture. Microbiol Mol Biol Rev. 2000;64:655-71.

70. Perovic DJ, Gamez-Virues S, Landis DA, Wackers F, Gurr GM, Wratten SD, et al. Managing biological control services through multi-trophic trait interactions: review and guidelines for implementation at local and landscape scales. Biol Rev. 2017;93:306-21.

71. Thomas MB. Biological control of human disease vectors: a perspective on challenges and opportunities. BioControl. 2017;63:61-9.

72. Zaneveld JR, Mcminds R, Vega TR. Stress and stability: applying the Anna Karenina principle to animal microbiomes. Nat Microbiol. 2017;2:1-8.

73. Bourne D, Iida Y, Uthicke S, Smith-Keune C. Changes in coralassociated microbial communities during a bleaching event. ISME J. 2008;2:350-63.

74. Apprill A, Hughen K, Mincer T. Major similarities in the bacterial communities associated with lesioned and healthy Fungiidae corals. Environ Microbiol. 2013;15:2063-72.

75. Godwin S, Bent E, Borneman J, Pereg L. The role of coralassociated bacterial communities in australian subtropical white syndrome of Turbinaria mesenterina. PLoS One 2012;7:e44243.

76. Meyer JL, Gunasekera SP, Scott RM, Paul VJ, Teplitski M. Microbiome shifts and the inhibition of quorum sensing by Black Band Disease cyanobacteria. ISME J. 2016;10:1204-16.

77. Ziegler M, Roik A, Porter A, Zubier K, Mudarris MS, Ormond R, et al. Coral microbial community dynamics in response to anthropogenic impacts near a major city in the central Red Sea. Mar Pollut Bull. 2016;105:629-40.

78. Santos HF, Cury JC, Carmo FL, Rosado AS, Peixoto RS. 18 S rDNA sequences from microeukaryotes reveal oil indicators in mangrove sediment. PLoS ONE. 2010;5:e12437.

79. Peixoto R, Chaer GM, Carmo FL, Araújo FV, Paes JE, Volpon A, et al. Bacterial communities reflect the spatial variation in 
pollutant levels in Brazilian mangrove sediment. Antonie Van Leeuwenhoek. 2011;99:341-54.

80. Andrade LL, Leite DCA, Ferreira EM, Ferreira LQ, Paula GR, Maquire MJ, et al. Microbial diversity and anaerobic hydrocarbon degradation potential in an oil-contaminated mangrove sediment. BMC Microbiol. 2012;12:186.

81. Rachid CT, Santos AL, Piccolo MC, Balieiro FC, Coutinho HLC, Peixoto RS, et al. Effect of sugarcane burning or green harvest methods on the brazilian cerrado soil bacterial community structure. PLoS ONE. 2013;8:e59342.
82. Barberán A, Bates ST, Casamayor EO, Fierer N. Using network analysis to explore co-occurrence patterns in soil microbial communities. ISME J. 2012;6:343-51.

83. Dini-Andreote F, de Cássia Pereira e Silva M, Triadó-Margarit X, Casamayor EO, van Elsas JD, Salles JF. Dynamics of bacterial community succession in a salt marsh chronosequence: evidences for temporal niche partitioning. ISME J. 2014;8:1989-2001.

84. Mallon CA, Van Elsas J, Salles J. Microbial invasions: the process, patterns, and mechanisms. Trends Microbiol. 2015;23: 719-29. 